\title{
Association between Handwashing Knowledge and Practices among the Students in Nepal
}

\author{
${ }^{1}$ Mohan Kumar Sharma \\ ${ }^{2}$ Shanti Prasad Khanal \\ ${ }^{3}$ Devaraj Acharya, PhD \\ ${ }^{4}$ Jib Acharya, PhD \\ ${ }^{1}$ Centre for Research on Education, Health and Social Science, Kathmandu, Nepal \\ ${ }^{2}$ Central Department of Education, Tribhuvan University, Kirtipur, Nepal \\ ${ }^{3}$ Faculty of Education, Bhairahawa Multiple Campus, Rupendehi, Nepal \\ ${ }^{4}$ Business Development and Health Research, ANC Premium Services Ltd., UK
}

Article History: Submitted 01 February 2021; Reviewed 20 April 2021; Accepted 26 April 2021

Corresponding Author: Mohan Kumar Sharma, Email: attrig2019@gmail.com

DOI: https://doi.org/10.3126/paj.v4i0.37005

Copyright 2021 ( ) Author/s and Centre for Research and Innovation.

This work is licensed under a Creative Commons Attribution 4.0 International (CC BY 4.0) License.
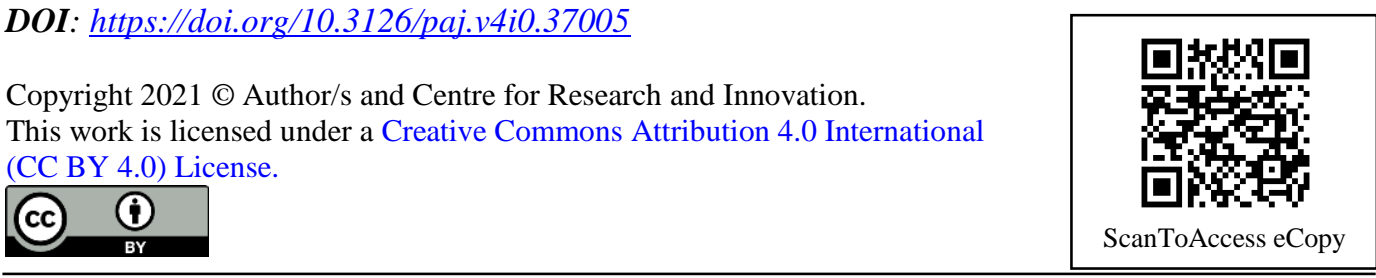

\begin{abstract}
Regular handwashing with soap and running water is one of the effective ways to stop spreading of germs that protects us from the disease. The aim of this study is to assess the handwashing knowledge and practice among the selected school students of Bardiya district in Nepal. To address this objective, the school-based descriptive cross-sectional design was applied. A total of 327 students including 9 to 12 grades were taken from four secondary schools using the multistage sampling technique. The validated selfadministrated questionnaires were used to collect the data from the selected students. Similarly, the univariate (frequencies and percentage) and bivariate analyses (chisquare test for association) were performed to analyse the data, using the Statistical Package of Social Science (SPSS) 26 versions. Out of the total participants, 29.7\% were between the ages of 15-16 years, 60.9\% were male, and the majority (95.7\%) were from Hindu. The study showed that $36.9 \%$ participants had the poor knowledge relating to handwashing. In contrast, it was found that $43.42 \%$ participants were found with the low practice of handwashing, which was higher than the knowledge level of handwashing. So having a good knowledge is not associated with good practices as regards to handwashing. It was noticed that the poor handwashing practice level remains higher as compared to the poor handwashing knowledge level. The study suggests that the schools have the responsibilities to give handwashing education to their students to raise the knowledge as well as the practice level of handwashing.
\end{abstract}

KEYWORDS: Community school, handwashing knowledge, handwashing practice, handwashing education 


\section{INTRODUCTION}

Hand hygiene is one of the most effective hand cleaning processes, which significantly condense potential pathogens on the hands and prevent the spread of infection. It is considered the principal measure to reduce the possibility of infection transmission through direct and indirect contact to persons and things. It is a milestone to control infectious disease and a significant public health measure (Jemal, 2018). Hands are the main pathways of harmful micro-organism spread (Meher \& Nimonkar, 2019). Consequently, more than thousands of people die every day around the world from infections which is getting hands-on by poor health hygiene (UNICEF, 2020). Thus, handwashing is a significant measure to keep away from the transmission of infectious disease.

The term "handwashing" refers to an act or process of cleaning one's hands to remove soil, grease, microorganisms, or other unwanted substances (PHAC, 2012). Handwashing with soap often and throughout the day prevents the spread of many diseases, for instance diarrhea (Cairncross et al., 2010), cholera (Hulland et al., 2013) and soil-transmitted helminthes (Strunz et al., 2014) which are transmitted through the fecal-oral route.

It has also been recognized as one of the most cost-effective health interventions to reduce the burden of disease (Bartram \& Cairncross, 2010). So, it refers to hand cleaning, including washing hands with water and soap (antimicrobial or nonantimicrobial) or applying an alcohol based hand sanitizer to the hands. It has always been one of most effective ways of keeping diseases at bay. A basic understanding of the poor hand washing behavior is it renders to transmission of pathogens through faces and a lesser extent of urine. The pathogens from faces are ingested through transmission by fingers, flies, fluids, fields (soil) and food.

Globally, every 20 seconds, a young child under the age of five years die due to poor sanitation (Hutton, 2012). The prominent causes of infant mortality as diarrheal disease are $11 \%$ and Acute Respiratory Infections (ARI) is $18 \%$ that are closely allied with insufficient hygiene practices (WHO, 2020). However, these two major infections can be preventable through the appropriate technique and timely hand hygiene practice. About one in every three incident of diarrheal diseases and one in every six episodes of ARI are preventable by washing hand with soap and water (Shresthaet al., 2018). So it can be said that handwashing with an effective procedure that does not consume much time or effort is appropriate to condense transmission of infection.

Hand hygiene is a fundamental component of health. It includes as do it yourself, vaccine it including simple but effective five steps: wet, lather, scrub, rinse and dry (Jefferson et al., 2008). So, it is one of the universally practised effective measures for infection prevention known as public health awareness (Shrestha et al., 2018). With the limited research relating to hand hygiene knowledge and practice among secondary school level students, this study assessed handwashing knowledge and practice among the selected school students of Bardiya district in Nepal.

\section{METHODS AND PROCEDURES Study Design}

A school-based descriptive cross-sectional design was applied to assess the knowledge and practices of handwashing among secondary level students of four community schools in Bardiya district of Nepal. 


\section{Study Area}

The study was confined to four secondary schools. The entire schools are found in Bardia district, which is located in Lumbini Province of Nepal, at a distance of $563 \mathrm{~km}$ from the capital city Kathmandu. There were more than the sample students in the schools while conducting the study (DECC) 2019, composed of basic and secondary level.

\section{Population, Sample Size and Sampling Procedure}

The population for this study was all students of preferred four schools studying in grade 9 to12. Altogether 1800 students were considered as a population of the study. The sample size was calculated using a standard formula with a five per cent margin of error at a 95 per cent confidence level. Therefore, the required sample size was 327. A simplified formula, $\mathrm{n}=\frac{\mathrm{N}}{1+\mathrm{N}(\mathrm{e}) 2}$ provided by Yamene (1967) was applied to calculate the sample size in this study. Where $\mathrm{n}$ denotes the sample size, $\mathrm{N}$ is the population size, and $\mathrm{e}$ is the level of precision. We applied this formula to obtain the sample size from the total population $\mathrm{N}=1800$ provided by District Education Coordination Committee (DECC) in 2019, we get a sample size $\mathrm{n}=327$ students. We consider, 95\% confidence level, and $\mathrm{p}=.5$ is the margin of error. Now, $\mathrm{n}=\frac{\mathrm{N}}{1+\mathrm{N}(\mathrm{e}) 2}, \mathrm{n}=\frac{1800}{1+1800(05) 2}=327$ students.

\section{Sampling Techniques and Procedures}

A multistage sampling technique was applied to select the students as study participants. Students were selected from grade standard 9, 10, 11, and 12 of the preferred four schools.

\section{Eligibility Criteria}

All students of four selected schools', who were available during data collection and interested in participating in the study, were included. Students who were not interested in participating in the study were excluded from this study.

\section{Data Collection Tools}

Self-administrated structured questionnaires were used to collect the data. The study questions were identified based on the objectives of the study. The questionnaire contained three different parts which included; socio-demographic characteristics, knowledge of handwashing, and practices of handwashing among students. The selfadministrated questionnaires were distributed to the students. Furthermore, they were instructed relating to the questionnaire how it filled up.

\section{Data Quality Assurance}

The researchers assured data quality through the reliability and validity of the research tools. Regarding its reliability, Nunun (1999) deals with the consistency and dependability of the results whereas validity compacts to trustworthiness, utility and dependability that the evaluator and the different stakeholders place into it. To remain tools valid, it was reviewed by the panel of experts' as (Bolarinwa, 2015) suggested. Meanwhile, based on the experts' comments the unclear and obscure questions were revised and complex items also were reworded. Furthermore, research tools were pretested in one different school from the sampled, near to study area to make tools reliable. Of the total 327 samples, 5\% (16 students) were participated in the pre-test for determining target groups reaction to the research tools. Later, the necessary correction 
was made on questionnaires that need correction accordingly and invalid questionnaires were removed before the actual raw data collection.

\section{Data Management and Analysis}

Initially, the obtained data from the field visit was edited, coded for completeness and validity. Then, it was entered into the Statistical Package of Social Science (SPSS) 26 versions use the new version and analyzed descriptively. Finally, the result was presented in the form of frequency tables, graphs, and charts where applicable. Besides, the chi-square test was conducted to find out the association between knowledge level and practices of handwashing among the study participants.

\section{Ethical Considerations}

Prior to the actual data collection, the head of the institutions (schools) was illustrated about the study purposes and importance that is going to be held. Immediately, permission was asked and obtained from the school authority. The process of data collection was started after the students were asked their willingness to participate and verbal consent was taken for the voluntary participant in this study. Furthermore, it was notified that they could withdraw from the study at any stage if they desired not to continue the study.

\section{RESULTS}

This section outlines the four key results of the research like the sociodemographic characteristic of the study participants, knowledge of the study participants towards handwashing, handwashing practices of study participants and the relation between knowledge level and handwashing practices of participants. The findings of this study are expected to help in many aspects such as better planning for awareness campaigns and to correct some untoward behaviors to stop the spread of the virus, which may result in rapid control and containment of the several diseases which borne from poor sanitation practices and poor hygiene behavior.

\section{Socio-Demographic Characteristics of the Study Participants}

Table 1 shows the demographic characteristic of the respondents. The demographic characteristic of the respondents is categorized based on age, gender, ethnicity and religion of the study participants. The below points describe the details of the demographic characteristics of the participants (see Table 1).

Table 1

Socio-demographic characteristics of the study participants

\begin{tabular}{llll}
\hline Variables & & Number & \% \\
\hline \multirow{4}{*}{ Age } & $\leq 14$ & 84 & 25.7 \\
& $15-16$ & 97 & 29.7 \\
& $17-18$ & 91 & 27.8 \\
\multirow{2}{*}{ Gender } & $\geq 19$ & 55 & 16.8 \\
\hline \multirow{3}{*}{ Ethnicity } & Male & 199 & 60.9 \\
& Female & 128 & 39.1 \\
\hline & Brahmin & 125 & 38.2 \\
& Chhetri & 143 & 43.7 \\
& Dalit & 20 & 6.1 \\
& Others & 39 & 11.9 \\
\hline
\end{tabular}

Prithvi Academic Journal, Volume 4, May 2021 [pp. 7-17] 


\begin{tabular}{llll}
\hline \multirow{3}{*}{ Religion } & Hindu & 313 & 95.7 \\
& Buddha & 5 & 1.5 \\
& Christian/others & 9 & 2.7 \\
\hline
\end{tabular}

Source: Field visit 2020

Out of 327 study participants, $29.7 \%$ were between the ages of 15-16 years, $27.8 \%$ were $17-18$ years of age, $25.7 \%$ were $\leq 14$ and the rest 16.8 were $\geq 19$ years of ages. Of the total, $60.9 \%$ were male participants. Considering the participants 'ethnicity, $43.7 \%, 38.2 \%, 6.1 \%$, and the remaining $11.9 \%$ were from the Brahmin, Chhetri, Dalit, and other castes respectively. The high majority $95.7 \%$ were from Hindu religion and less $2.1 \%$, were from Christian, $1.5 \%$ were Buddhist, and rest $0.6 \%$ participants were considered to other religion.

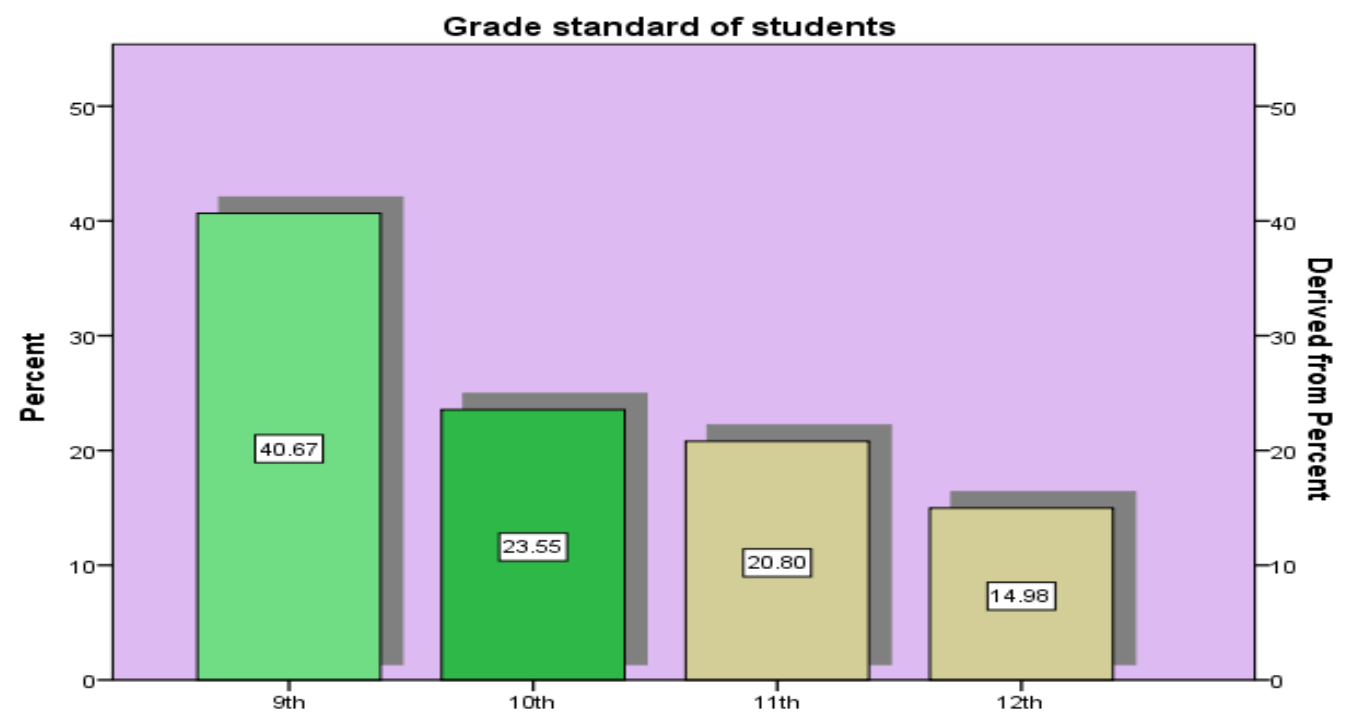

Figure 1. Frequency of students by their grade standards

Figure 1 is evidence for the frequency distribution of study participants by the grade of standards in which $40.7 \%, 23.5 \%, 20.8 \%$, and the remaining $15 \%$ were from the $9^{\text {th }}, 10^{\text {th }}, 11^{\text {th }}$ and $12^{\text {th }}$ grade standards respectively.

\section{Knowledge of study participants towards handwashing}

Table 2 summarized the participants' knowledge on handwashing in which results are showed in simple statistical analysis like frequency and percentages. Participants knowledge on handwashing was measured by asking 10 questionnaires are presented as,

Table 2

Hand washing knowledge of study participants

\begin{tabular}{lllllll}
\hline Variables & $\begin{array}{l}\text { Yes } \\
\text { Frequency }\end{array}$ & \% & $\begin{array}{l}\text { No } \\
\text { Frequency }\end{array}$ & \% & \multicolumn{2}{c}{$\begin{array}{l}\text { Not applicable } \\
\text { Frequency }\end{array}$} \\
\hline $\begin{array}{l}\text { Do you think hand } \\
\text { washing should be } \\
\text { done with soap and } \\
\text { water? }\end{array}$ & & 75.8 & 53 & 16.2 & 26 & 8.0 \\
\hline $\begin{array}{l}\text { Do you think } \\
\text { applying the 6 steps }\end{array}$ & 237 & 72.5 & 62 & 19.0 & 28 & 8.6 \\
\hline
\end{tabular}

Prithvi Academic Journal, Volume 4, May 2021 [pp. 7-17] 


\begin{tabular}{|c|c|c|c|c|c|c|}
\hline $\begin{array}{lr}\text { of handwashing } \\
\text { methods } \\
\text { important } & \text { while } \\
\text { washing } & \text { your } \\
\text { hands? } & \end{array}$ & & & & & & \\
\hline $\begin{array}{l}\text { Do you think we } \\
\text { should spend almost } \\
20 \text { seconds while } \\
\text { washing our hands? }\end{array}$ & 253 & 77.4 & 57 & 17.4 & 17 & 5.2 \\
\hline $\begin{array}{l}\text { Are hands washing } \\
\text { is important before } \\
\text { and after preparing } \\
\text { food? }\end{array}$ & 257 & 78.6 & 62 & 19.0 & 8 & 2.4 \\
\hline $\begin{array}{lr}\text { Do you } & \text { think } \\
\text { handwashing } & \text { is } \\
\text { significant } & \text { before } \\
\text { eating food? } & \\
\end{array}$ & 243 & 74.3 & 73 & 22.3 & 11 & 3.4 \\
\hline $\begin{array}{l}\text { Are hands washing } \\
\text { important after } \\
\text { blowing the nose, } \\
\text { coughing, } \\
\text { sneezing? }\end{array}$ & 259 & 79.2 & 50 & 15.3 & 18 & 5.5 \\
\hline $\begin{array}{l}\text { Are the hands } \\
\text { should be washed } \\
\text { after using the } \\
\text { toilet? }\end{array}$ & 290 & 88.7 & 16 & 4.9 & 21 & 6.4 \\
\hline $\begin{array}{l}\text { Do you think hand } \\
\text { washing is important } \\
\text { after touching an } \\
\text { animal, animal feed, } \\
\text { or animal waste? }\end{array}$ & 244 & 74.6 & 67 & 20.5 & 16 & 4.9 \\
\hline $\begin{array}{l}\text { Do you think that } \\
\text { the hands should be } \\
\text { washed after } \\
\text { handling pet food or } \\
\text { pet treats? }\end{array}$ & 214 & 65.4 & 88 & 26.9 & 25 & 7.6 \\
\hline $\begin{array}{l}\text { Is the hand-washing } \\
\text { process being one of } \\
\text { the most effective } \\
\text { methods to prevent } \\
\text { and spread } \\
\text { infection? }\end{array}$ & 248 & 75.8 & 45 & 13.8 & 34 & $\begin{array}{l}10 . \\
4\end{array}$ \\
\hline
\end{tabular}

Source: Field visit 2020

Out of a total of 327, one-third (75.8\%) of participants' responded hands should be washed with soap and water were the same proportion emphasized it is one of the most effective methods to prevent and spread of infection. Likewise, $72.5 \%$ of participants' revealed 6 steps method for handwashing is significant and the slightly high proportion (77.4\%) than that disclosed almost 20 seconds hand washing period. Of the total, $88.7 \%$ articulated hands should be washed after using the toilet where $74.3 \%$ expressed washing hands before eating is crucial to prevent infection.

Prithvi Academic Journal, Volume 4, May 2021 [pp. 7-17] 


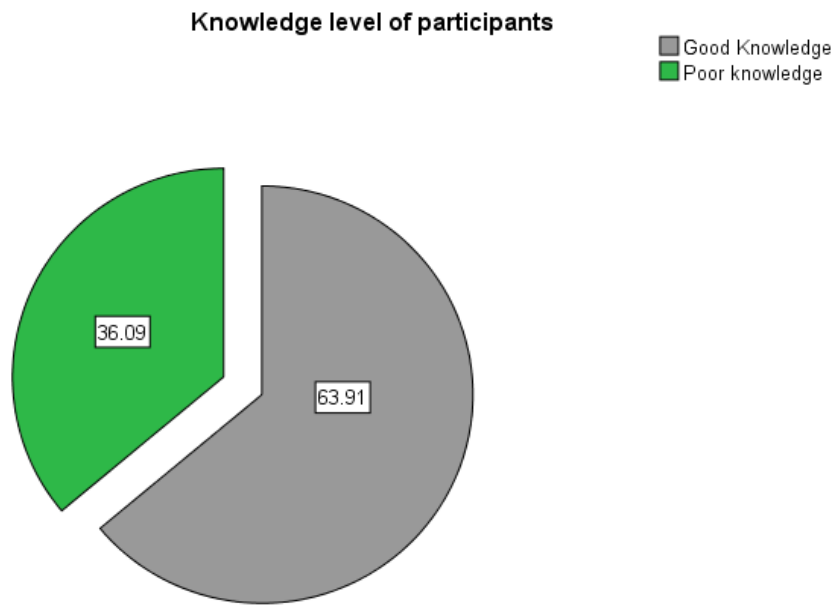

Fig. 1. Knowledge level of participants

Figure 2 shows the knowledge category of the study participants relating to handwashing in which majorities (63.9\%) had good knowledge whereas rest 36.9\% had found with poor.

\section{Handwashing Practices of Study Participants}

Table 3 represents the frequency of handwashing practices by the study participants. In order to assess the handwashing practices of participants 10 questionnaires are administrated. The obtained responses are summarized in the below table.

Table 3

Handwashing practices of study participants

\begin{tabular}{|c|c|c|c|}
\hline Variables & Responses & Frequency & $\%$ \\
\hline \multirow{4}{*}{$\begin{array}{l}\text { Do you wash your hands with soap } \\
\text { and water immediately after reaching } \\
\text { home? }\end{array}$} & Always & 248 & 75.8 \\
\hline & Usually & 50 & 15.3 \\
\hline & Sometimes & 17 & 5.2 \\
\hline & Not applicable & 12 & 3.7 \\
\hline \multirow{4}{*}{$\begin{array}{l}\text { Do you apply } 6 \text { steps of the } \\
\text { handwashing process while washing } \\
\text { your hands? }\end{array}$} & Always & 227 & 69.4 \\
\hline & Usually & 45 & 13.8 \\
\hline & Sometimes & 30 & 9.2 \\
\hline & Not applicable & 25 & 7.6 \\
\hline \multirow{4}{*}{$\begin{array}{l}\text { Do you spend almost } 20 \text { seconds } \\
\text { while washing your hands? }\end{array}$} & Always & 247 & 75.5 \\
\hline & Usually & 57 & 17.4 \\
\hline & Sometimes & 15 & 4.6 \\
\hline & Not applicable & 8 & 2.4 \\
\hline \multirow{4}{*}{$\begin{array}{l}\text { Do you wash your hands with soap- } \\
\text { water before and after preparing } \\
\text { food? }\end{array}$} & Always & 257 & 78.6 \\
\hline & Usually & 37 & 11.3 \\
\hline & Sometimes & 17 & 5.2 \\
\hline & Not applicable & 16 & 4.9 \\
\hline \multirow{3}{*}{$\begin{array}{l}\text { Do you wash your hands before } \\
\text { eating food? }\end{array}$} & Always & 310 & 94.8 \\
\hline & Usually & 17 & 5.2 \\
\hline & Sometimes & - & - \\
\hline
\end{tabular}

Prithvi Academic Journal, Volume 4, May 2021 [pp. 7-17] 


\begin{tabular}{|c|c|c|c|}
\hline & Not applicable & - & - \\
\hline \multirow{4}{*}{$\begin{array}{l}\text { Do you wash your hands after } \\
\text { blowing the nose, coughing, or } \\
\text { sneezing? }\end{array}$} & Always & 247 & 75.5 \\
\hline & Usually & 57 & 17.4 \\
\hline & Sometimes & 18 & 5.5 \\
\hline & Not applicable & 5 & 1.5 \\
\hline \multirow{4}{*}{$\begin{array}{l}\text { Do you wash your hands after using } \\
\text { the toilet? }\end{array}$} & Always & 275 & 84.1 \\
\hline & Usually & 25 & 7.6 \\
\hline & Sometimes & 15 & 4.6 \\
\hline & Not applicable & 12 & 3.7 \\
\hline \multirow{4}{*}{$\begin{array}{l}\text { Do you wash your hands after } \\
\text { touching an animal, animal feed, and } \\
\text { animal waste? }\end{array}$} & Always & 158 & 48.3 \\
\hline & Usually & 96 & 29.4 \\
\hline & Sometimes & 35 & 10.7 \\
\hline & Not applicable & 38 & 11.6 \\
\hline \multirow{4}{*}{$\begin{array}{l}\text { Do you wash your hands after } \\
\text { handling pet food or pet treats? }\end{array}$} & Always & 219 & 67.0 \\
\hline & Usually & 70 & 21.4 \\
\hline & Sometimes & 20 & 6.1 \\
\hline & Not applicable & 18 & 5.5 \\
\hline \multirow{4}{*}{$\begin{array}{l}\text { Dou you wash your hands after } \\
\text { touching or handling garbage? }\end{array}$} & Always & 187 & 57.2 \\
\hline & Usually & 89 & 27.2 \\
\hline & Sometimes & 31 & 9.5 \\
\hline & Not applicable & 20 & 6.1 \\
\hline
\end{tabular}

Source: Field visit 2020

Of the total, one-third (75.5\%) proportion expressed they always wash hands with soap and water after reaching home and after blowing nose, coughing, and sneezing. The proportion of handwashing before having food was higher $94.8 \%$ than those who washed hands before toileting $84.1 \%$. Less than half (48.3\%) participants have practised washing hands after touching an animal, animal feed and animal waste.

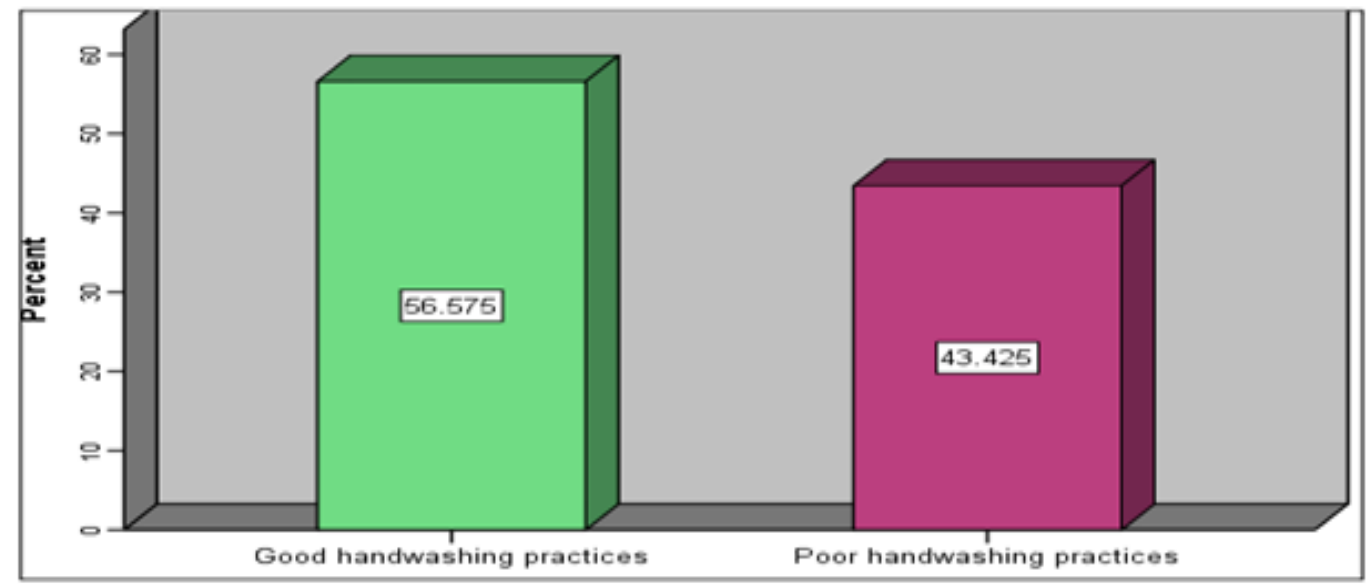

Figure 3. Handwashing practices level by study participants

Figure 3 portrays handwashing practices by the study participants. The practice is calculated and analyzed into two categories as good handwashing practices and poor. Of the total, majorities (56.57\%) participants were found having good handwashing practices where $43.42 \%$ had found poor handwashing practices. 


\section{The Relation between Knowledge Level and Handwashing Practices.}

This section signifies the mean; association between knowledge level and practices in relation to handwashing behavior of the participants. A summary of these results are presented in the table below.

Table 4

Chi-Square test of knowledge and handwashing practices

\begin{tabular}{|c|c|c|c|c|c|}
\hline & Value & Df & $\begin{array}{l}\text { Asymp. Sig. } \\
\text { (2-sided) }\end{array}$ & $\begin{array}{l}\text { Exact } \\
\text { (2-sided) }\end{array}$ & $\begin{array}{l}\text { Sig. Exact } \\
\text { (1-sided) }\end{array}$ \\
\hline Pearson Chi-Square & $.271 \mathrm{a}^{\mathrm{a}}$ & 1 & .603 & .000 & .000 \\
\hline Continuity Correction ${ }^{b}$ & .164 & 1 & .686 & & \\
\hline Likelihood Ratio & .272 & 1 & .602 & .000 & .000 \\
\hline Fisher's Exact Test & & & & .643 & .343 \\
\hline $\begin{array}{l}\text { Linear-by-Linear } \\
\text { Association }\end{array}$ & .270 & 1 & .270 & .603 & .000 \\
\hline $\mathrm{N}$ of Valid Cases & 327 & & & & \\
\hline
\end{tabular}

Note: Chi square test $* * *=\mathrm{P}<0.001, * *=\mathrm{P}<0.01$ and $*=\mathrm{p}<0.05$

Table 4 shows the association between the knowledge level of study participants and their handwashing practices at a $99 \%$ confidence level. As per the survey data, the knowledge level of participants has no association with handwashing practices. In analogous words, having good knowledge does not mean participants have good practices as regards handwashing.

\section{DISCUSSION}

The current study examined the handwashing knowledge level and practice of participants. This study found that of the total participants, the majority of participants (63.9\%) had good knowledge and remained $36.9 \%$ found with poor knowledge towards handwashing. In support of the present findings, research conducted by (Jemal, 2018) in which the author revealed $65.93 \%$ were knowledge and $34.07 \%$ were not knowledgeable. A study conducted by Manandhar and Chandyo (2018) concluded that students had handwashing knowledge; proper handwashing practices were lagging. Another study conducted in Bhaktapur found that secondary school students of Bhaktapur have good knowledge of personal hygiene while a lot more improvement is required in terms of practices (Rajbhandari et al., (2018). We supposed the knowledge level of the health profession is higher than school-aged children relating to handwashing; however, the study found that it is only slightly high than school children. This might be due to the status of the organizations (school and hospital), period of the study, differ background of the study participants. Hossain (2016) conducted a study in Bangladesh that reported the widespread insufficient hand hygiene practice in universitygoing students.

Our study found that out of a total of 327 participants, the majority (56.57\%) with good handwashing practices where the rest $43.42 \%$ with poor practices. In line with the present findings, Sultana et al. (2016) indicates that most respondents maintained hand hygiene practices; however, they sufficiently enough not mentioned during the process like 20 seconds time duration and 6 steps of procedures. The reason for not practising handwashing properly may participants' mindset to keep forgetting, their environment, and poor handwashing sources: soap and water. Our study concluded that the knowledge level of participants has no association with handwashing practices. But a study conducted in India showed the opposite finding than that correct handwashing techniques with a statistically significant $\mathrm{P}$ value of 0.015 . Correct handwashing 
techniques were statistically associated with the education of the children's mothers with a P-value of 0.001 (Sangha et al., 2020). Tamilarasi et al. (2016) conducted a study in Chennai found that there is a statistically significant association present between adequate handwashing practice and adequate knowledge of handwashing.

\section{CONCLUSION}

Based on our analysis of the collected data, the majority of students had good knowledge and practices towards handwashing; however, the proportion of good practices remains low. Similarly, poor handwashing practice remains high compared to poor handwashing knowledge. Regular handwashing with soap and water applying appropriate procedure is crucial to prevent people from several infections. Therefore, schools have the responsibilities to teach handwashing education to their students and also to protect them from the several bacterial diseases caused by poor hand hygiene. Further, the responsibility equally goes to the family members to provide hand hygiene behavior. To conclude, several parts remain to investigate on these issues, so researchers recommended further exploration on this issue.

\section{ACKNOWLEDGEMENTS}

We are highly grateful to all schools and student participants for taking part in our study and sharing knowledge and practices as regards to handwashing practices. Furthermore, we also owe our sincere gratitude to the researchers whose research articles we used in this study.

\section{REFERENCES}

Bolarinwa, O. A. (2015). Principles and methods of validity and reliability testing of questionnaires used in social and health science researchers. Nigerian Post Graduate Medical Journal, 4. https://pubmed.ncbi.nlm.nih.gov/26776330

Cairncross, S., Hunt, C., Boisson, S., Bostoen, K., Curtis, V., Fung, I. C., \& Schmidt, W. P. (2010). Water, sanitation and hygiene for the prevention of diarrhoea. International journal of epidemiology, 39 Suppl 1(Suppl 1), i193i205. https://doi.org/10.1093/ije/dyq035

Hulland, K. R., Leontsini, E., Dreibelbis, R., Unicomb, L., Afroz, A., Dutta, N. C., Nizame, F. A., Luby, S. P., Ram, P. K., \& Winch, P. J. (2013). Designing a handwashing station for infrastructure-restricted communities in Bangladesh using the integrated behavioural model for water, sanitation and hygiene interventions (IBM-WASH). BMC public health, 13, 877. https://doi.org/10.1186/1471-2458-13-877

Hutton, G. (2012). Global costs and benefits of drinking water supply and sanitation interventions to reach the MDG target and universal coverage, Geneva, Switzerland. World Health Organization (WHO). http://www.who.int/ about/licensing/copyright_form/en/index.html

Jefferson T, Del Mar C, Dooley L, Ferroni E, Al -Ansary LA, Bawazeer GA. (2018). Physical interventions to interrupt or reduce the spread of respiratory viruses: Systematic review. BMJ, 336, 77.

Jemal, S. (2018). Knowledge and practices of hand washing among health professionals in Dubti Referral Hospital/ Dubti, Afar, Northeast Ethiopia, 1-8. https://go.gale.com/ps/anonymous?id=GALE\%7CA574695098\&sid=googleSch olar\&v=2.1\&it=r\&linkaccess $=$ abs \&issn $=20903499 \& \mathrm{p}=\mathrm{AONE} \& \mathrm{sw}=\mathrm{w}$

Manandhar, P., \& Chandyo, R. (2018). Hand washing knowledge and practice among school going children in Duwakot, Bhaktapur: A cross sectional study. Journal 
of Kathmandu Medical College, 6(3), 110-115. https://doi.org/10.3126/ jkmc.v6i3.19827

Meher, S., \& Nimonkar, R. (2019). School in Kolkata Study of hygiene practices among school going children in a government school in Kolkata. International Journal of Community Medicine and Public Health (IJCMPH), 5(7), 3102-3105. https://doi.org/10.18203/2394-6040.ijcmph20182655

Nunan, D. (1999). Second language teaching and learning. Heinle\&Heinle. https://scholar.google.com/scholar?q=Nunan,+D.+(1999).+Second+language+te aching+and+learning.+Boston:+Heinle+\%26+Heinle.\&hl=en\&as_sdt=0\&as_vis $=1 \&$ oi $=$ scholart

PHAC. (2012). Hand hygiene practices in health care settings. Infection Disease Prevention and Control @ Her Majesty the Queen in Right of Canada.

Rajbhandari AK, Dhaubanjar R, GC KB, Dahal M. (2018). Knowledge and practice of personal hygiene among secondary school grade nine and ten students. Journal of Patan Academy of Health Science. https://doi.org/10.3126/jpahs.v5i2.24030

Sangha NK, Kaur P, Sidhu TK, Gill NK., (2020). A cross sectional study to assess knowledge and practices of hand washing among primary school children in the Kapurthala District, India. Int. J. School. Health, 7(3), 1-5.

Shrestha, S., Yadav, R. S., \& Sharma, S. (2018). Hand washing at peripheral health facilities of Kathmandu, an overlooked practice. Journal of Microbiology Research Society (JMRS), 1(1), 1-3.

Sultana M, AlamMahumud R, RazzaqueSarker A, Mahmud Hossain S. (2016). Hand hygiene knowledge and practice among university students: Evidence from Private Universities of Bangladesh. Risk Management Health Policy, 9, 13-20. https://doi.org/10.2147/RMHP.S98311

Strunz EC, Addiss DG, Stocks ME, Ogden S, Utzinger J, et al. (2014). Water, sanitation, hygiene, and soil-transmitted helminth infection: A systematic review and metaanalysis. PLOS Medicine, 11(3), e1001620. https://doi.org/10.1371/ journal. pmed. 1001620

Tamilarasi R. et al. (2016). A study to assess the knowledge and practice of hand washing among school going adolescents in Chennai. Internal Journal of Health Sciences and Research (IJHSR), 6(8), 147-155.

UNICEF. (2016). UNICEF Annual Report, 2016. C United Nations Children's Fund (UNICEF), June 2017.

WHO. (2010). World Health Stastics. World Health Organization (WHO) () World Health Organization 2010, 20 Avenue Appia, 1211 Geneva 27, Switzerland.

Yamane, Taro. (1967). Statistics, an introductory analysis (2nd ed.). Harper and Row. https://www.tarleton.edu/academicassessment/documents/samplesize.pdf 